ISSN 1816-6075 (Print), 1818-0523 (Online)

Journal of System and Management Sciences

Vol. 9 (2019) No. 1, pp. 48-68

DOI:10.33168/JSMS.2019.0103

\title{
The Vision 2030: Corporate Governance Perspective in Saudi Arabia
}

\author{
Faisal Bin Hammad \\ Accounting Department, College of Business Admiration, University of Hail \\ faisal22_uhsa@gmail.com
}

\begin{abstract}
This paper reviews the relationships between the prevention system of Corruption, corporate governance (CG) and economic development in Kingdom of Saudi Arabia. The drive behind the Saudi transformationaleconomic started is attributable to a spread of things just like the drop in the oil prices in 2015-2016, OPEC's member's disagreement on reducing productions, the invention of oil in North America etc. In spite of the new changes on Kingdom of Saudi Arabia main oil- revenue generating mechanism, McKinsey's report of 2015 is suggesting that their planned "productivity-led transformation model of the Saudi economy" is capable of 1) changing the sector of the Saudi economy 2) developing new productivity and growth venues 3) doubling Saudi brand value, 4) inventing as many as six million new Saudi jobs by 2030. Moreover, such social enterprise is calculable by McKinsey to cost $\$ 4$ trillion in investments. To boot, McKinsey's report allegedly highlights eight existing sectors namely: mining \& metals, petrochemicals, producing, retail and wholesale trade, business enterprise and welcome, health care, finance, and construction and turning out with are capable of tributary over hour of the overall growth needed to double Saudi worth by 2030. Moreover, the McKinsey report signifies the grouping responsibility and responsibility to accelerate and reach the desired goals of their "comprehensive model that integrates the Kingdom's economic, marketplace, and public finance perspectives" via a collective effort. Not entirely that but the report to boot signifies the roles Saudi private companies and international companies can play in reworking the Saudi economy and "accelerate the Kingdom's modernization". Above all, the special company governance issues with banks, family-owned firms, and state-owned firms are not well understood; neither square measure the character and determinants of public and private group action. The study aims likewise to review the foremost very important criteria and altogether totally different comprehensive
\end{abstract}


principles of governance in light-weight of the institutional framework that organizes its work nature \& Socio-economical, institutional, and privatization factors that may influence the implementation of Saudi vision of 2030. Consequently, this paper presented descriptive analysis on the thought of secondary sources like from Saudi Central Department of Statistics and information \& Saudi Ministry of Economy and complete by characteristic major policy recommendations and analysis issues that require additional study.

Keywords: Vision 2030, Saudi Arabia, National Economy, Brand Value, Privatization on Economy, Non-Oil Based Industry

\section{Introduction}

The Saudi government has been started working on anti-corruption system, More than 200 people have been summoned for questioning, and most are still detained, in a wide-ranging crackdown that Saudi Arabia says is aimed at rooting out corruption and reclaiming embezzled funds. The kingdom's attorney general, Sheikh Saud al-Mojeb, said in a statement that Saudi authorities believed that at least $\$ 100$ billion "had been misused though systematic corruption and embezzlement over several decades." and campaign was a necessary part of Prince Mohammed's efforts to clean up the economy to attract international investors (Vision 2018). Two decades ago, the term corporate governance meant little to all but a handful of scholars and shareholders. Today, it is a mainstream concern a staple of discussion in corporate boardrooms, academic roundtables, and policy think tanks worldwide. Several events are responsible for the heightened interest in corporate governance. During the wave of financial crises in 1998 in Russia, Asia, and Brazil, the behavior of the corporate sector affected entire economies, and deficiencies in corporate governance endangered the stability of the global financial system. Just three years later, confidence in the corporate sector was sapped by corporate governance scandals in the United States and Europe that triggered some of the largest insolvencies in history (AlRuthia, Alsenaidy et al. 2018). And the most recent financial crisis has seen its share of corporate governance failures in financial institutions and corporations, leading to serious harm to the global economy, among other 
systemic consequences. In the aftermath of these events, economists, the corporate sector, and policymakers worldwide recognize the potential macroeconomic, distributional and long-term consequences of weak corporate governance systems. The crises however are manifestations of several structural factors and underscore why corporate governance has become even more central for economic development and society's well-being. The private, market-based investment process is now much more important for most economies than it used to be; that process needs to be underpinned by better corporate governance. With the size of firms increasing and the role of financial intermediaries and institutional investors growing, the mobilization of capital has increasingly become one step removed from the principal-owner. The allocation of capital has also become more complex as investment choices have multiplied with the opening up and liberalization of financial and real markets. Structural reforms, including price deregulation and increased competition, have broadened companies"e exposure to market forces. These developments have made the monitoring of the uses of capital more complex in many ways, enhancing the need for good corporate governance (Krane and Majid 2018).

The International Finance Corporation (IFC) defines corporate governance as the structures and processes by which companies are directed and controlled. Good corporate governance helps companies operate more efficiently, improve access to capital, mitigate risk and safeguard against mismanagement. It makes companies more accountable and transparent to investors and gives them the tools to respond to stakeholder concerns. Corporate governance also contributes to development. Increased access to capital encourages new investments, boosts economic growth, and provides employment opportunities.

\section{Importance and Need of the Study}

The corporate governance concept has a great importance due to the crackdown on corruption system, financial declines and economic crises which several states 
have witnessed in the money markets and corporations located in a number of states in East Asia, Latin America and Russia during the 1990s of the twentieth century. Governance can be defined as the corporationse rational governance through a group of laws, rules and bases that guarantee transparency and law enforcement. Furthermore, the US economy has lately witnessed financial and accounting declines and the world financial crisis of 2008-2009 whose one of its most important reasons is related to the lack of transparency and disclosure of the financial and accounting data of a number of corporations and economic units of the money markets.

Saudi Arabia's Strategic vision 2030: the leaders, the public and those in charge of administering the corporations should possess long- term vision for good governance and development in parallel with the requirements of the development. There is a close relationship between good governance and economic development process. The good governance has become in its all dichotomies a main condition to achieving the continued development through creating the legal, economic and social circumstances necessary for liberating these human abilities and hence reinforcing the human welfare through eliminating poverty, creating job opportunities, preserving environment and elevating the position of women empowerment by eliminating corruption system in the kingdom.

\section{Objective of the Study}

- To review the literature of the corporate governance with reference to oilbased economies

- To address the corporate governance structure \& theoretical frame work in Saudi towards

- Saudi vision 2030

- To address the Factors Influencing the CG Regime of Saudi Economy

- To address the role of corporate governance in elimination of corruption 
- To offer suggestions for better implementation of the corporate governance

\section{Hypothesis and Research Justification}

H1: There is a significant gap between the nature of capitalism and the crisis of control over the business in Saudi Arabia.

H2: there are Factors that can influence the implementation of Saudi 2030 vision from a $\mathrm{CG}$ perspective.

This study comprehensively addresses the knowledge gap by devising a conceptual framework, incorporating Socio-economical, institutional, and privatization factors, capable of unveiling the challenges vision 2030 might face from a $\mathrm{CG}$ perspective. Hence, this framework will contribute to a greater understanding of the influence of McKinsey 2015 report on Saudi CG practice and propose corresponding resolutions to overcome potential challenges in eliminating corruption in Saudi Arabia.

\section{Research Methodology}

The data has been gathered through secondary source i.e., reports, statistical abstracts, websites of OECD and other useful sources, reputed journals \& newspapers and the present study is descriptive analysis in nature, for analysis, all the condensed data being presented in two-way tabular form with crosssectional comparative analysis for drawing the inferences.

\section{The Role of Corporate Governance in Elimination of Corruption}

KSA Govt. has identified corporate governance as a corruption eliminating tool, the importance of corporate governance has increased at utmost as a tool for addressing anticorruption system, which is essential when organizations start to understand the fact that corporate governance is not an issue of legislation, but a 
way to building sustainable businesses across the world. Corruption is a corrosive drain on public trust and on the legitimacy of public and private sector organizations. The important way of addressing corruption problem through internal measures is the establishment of strong corporate governance within companies. Good corporate governance is not only a tool that raises efficiency, improves access to capital, and ensures sustainability-it is also emerging as an effective anti-corruption tool. On the day-to-day transaction level it makes bribes more difficult to give and to conceal. At the decision-making level, corporate governance injects transparency and accountability, so that it is very clear how decisions are made and why.

Finally, underlying the very roots of corporate governance and providing its moral compass, is ethics. Companies operating or planning to invest in Saudi Arabia face a high risk of corruption. Abuse of power, nepotism and the use of middlemen (WASTA) to do business are particularly common. Social elite heavily influence the oil and petrochemicals sectors. Gifts are regulated under Saudi law, but facilitation payments are not addressed. In fact, legislation such as the U.S. Foreign Corrupt Practices Act (FCPA) or the United Kingdom Bribery Act places legal responsibility on companies for the behavior of their suppliers and distributors in global value chains. The principles underlying good corporate governance and business ethics are deeply rooted in universal values. The Universal Declaration of Human Rights has established a global consensus on the applicability of shared moral principles across various countries. Many of these principles that deal with individual rights such as right to property and equal treatment under the law are now reflected in landmark documents on ethical business behavior: OECD Anti-Bribery Convention; United Nations (UN) Convention against Corruption; World Economic Forum's Partnering Against Corruption Initiative; Transparency International's Business Principles for Countering Bribery; International Chamber of Commerce Rules of Conduct to Combat Extortion and Bribery; and the UN Global Compact's 10th Principle, among others. Growth of strong national anti-corruption legislation such as 
Foreign Corrupt Practices Act (FCPA) and United Kingdom Bribery Act (UKBA) also affects the emerging global standards.

\section{CG and Its Applicable Sharia Laws in Saudi Arabia}

CG regulations in Saudi Arabia have been relatively premature due to the late significance attached to adopting a sound CG system after the first market crash of 2006. A few governmental agencies have played key roles in setting the stage for implementing appropriate CG standards in Saudi Arabia such as SCC, SMCI, SOCPA, and SHEC. Nevertheless, it can still be said that the main legislative sources of CG in Saudi Arabia stem from.

- The Companies Act of 1965: initially considered the first legislative attempt at establishing general CG guidelines.

- $\quad$ The Saudi Capital Market Law of 2004 (SCMA): practically, the first legislative attempt to organize the Saudi Capital Market's operations of listed corporations

\section{Review of Literature}

In order to clearly understand the gravity of the Economic Development through Corporate Governance with special reference to vision 2030 Saudi economy \& GCC topic, extensive reviews of various reports, working papers, dissertations and academic journals were reviewed on the socio-economical, institutional, and privatization factors to assess the challenges of vision 2030 from a CG perspective of Saudi, few of them have been listed here. According to Dean, (2006), "We needed people with vision prepared to make investment in governance because the long term returns are worth it”. Rossouw and Sison. (2006), state, "Corporate governance regimes around the world shaped by different sets of cultural values are also divided with regard to the question: for whose benefit should corporations be governed?" Therefore, socio-economical, institutional, and privatization factors are very crucial to consider when assessing 
the strength of any GC regime worldwide.

La Porta, Lopez-de-Silanes, Shleifer, and Vishny. (2002), where minority rights are strongly protected in law, then, this framework illuminates many of the problems confronted by firms and their investors and worldwide comparative work empirically shows that higher dividend pay outs, high compliance with international accounting standards and the open disclosure required of listed companies are effective indicators of a strong CG regime. Their analysis also confirms the proposition that shareholders are better served when compliance and disclosure are transparent. However, Agency Theory breaks down where there is a lack of homogeneity in the interests of individual stakeholder groups.

In Saudi Arabia, corporate governance is a newly introduced regime. Its set of CG principles was initially issued in 2006, after the first market crash in 2006, as such crash has signified the need for appropriate CG standards in Saudi Arabia (Al-Zahrani, 2013). After the first and second market crashes in 2006 and 2008, adherence to CG principles was made obligatory in 2010 (Al-Zahrani, 2013). Nevertheless, CG legislations in Saudi Arabia is still slowly moving from voluntary to obligatory as family-owned firms, as argued by Koldertsova (2011), are stifling corporate growth by their reluctance to open their equity to outside shareholders.

The dominant form of incorporations, in Saudi Arabia, is a family-controlled block holding and they are slowing the growth of the $\mathrm{CG}^{\mathrm{ee}} \mathrm{s}$ regulatory compliance framework (Koldertsova, 2011). Minority shareholders have suffered catastrophic losses from initial Public Offers in 2006 and 2008, and Saudi CG regulations are still adhered to on a ' comply or explain basis' (Al-Zahrani, 2013). As a result, Saudi shareholders, "even in accordance with SCL [Saudi Company Law of 1965] are weak; this law does not provide shareholders with all the rights that they should enjoy. Thus, minority shareholders are often subject to the control of majority shareholders, who are generally in charge of the company's management"(Al-m Zahrani, 2013).Hence, the protection of minority 
shareholders (being those who do not have a controlling influence in the firm) is a primary concern in the area of $\mathrm{CG}$ and particularly as defined by the Organization for Economic Co-operation and Development (OECD) principles. In fact, this agency cost is very recognizable in listed Saudi corporations as their issues of CG compliance and disclosure partially stem from a highly concentrated ownership structures found within these corporations. Moreover, the determinants promoting or influencing that concentrated ownership structure are not clear: families own $75 \%$ of listed companies, while government and individual founders own just $25 \%$ of listed companies (Al-Zuhair, 2008).

Therefore, Berle's and Means's (1932) assumption of listed corporations' shares being massively dispersed in the long run has been challenged by researchers in CG specializing in the law area. In a study aimed at identifying the ultimate shareholders of large corporations in 27 countries, findings suggest a whole different picture than the one predicted by Berle and Means. (La Porta et al., 2002). Firstly, in countries where there are weak shareholders' protections, most large corporations are found dominated by controlling shareholders such as states, or families. Secondly, these controlling shareholders are found to have excessive control over large corporations exceeding their cash flow rights through pyramidal structures and other controlling means. Hence, large corporations in these weakly legislated investors' protection countries are found to have a dilemma of separation of ownership and control but it is far from what was predicted by Berle and Means (1932). Thirdly, these controlling families are found set to monitor top management which are found to be members of controlling families. Thus, these controlling families are found to have the power and interest to expropriate minority shareholders. Fourthly, controlling families are found not to support neither encourage legal reforms enhancing minority shareholders"e rights. Instead, these families are found to lobby against such reforms (La Porta et al., 2002). Fifthly, La Porta et al., state, "ownership concentration is a consequence of poor legal protection of minority shareholders"(1999). 
In addition to that the political literature on CG is seen as the bridge between the legal rules and economic developments. Hence, some political theories have been proposed to explain CG. For instance, Pagano and Volpin (2005) explain the rational of their proposed model as, " company law can be changed by politicians easily any time: having a political economy model can formalize the behavior of voters and politicians in response to the economic interest as well as their ideologies". Moreover, once the concentrated ownership structure transforms into Crony capitalism, uniting both the political and the economic powers, the effect of the law becomes minimal (Coffee, 2001). Therefore, Gourvevitch (2008) proposes the fact that an understanding of the change in CG requires an understanding of the "broader changes in the polity that make[s] and enforce[s] those rules which shape corporate governance practices." Through lobbying, Wealth concentration might have negatively affected the evolution of the legal and other institutional frameworks for corporate governance and the manner in which economic activity is conducted. It could be a formidable barrier to future policy reform. Concentration of control might also have been a detriment to the evolution of the countries' legal systems. A concentrated control structure of the whole corporate sector could lead to the suppression of minority rights and hold back the institutional development of legal and regulatory channels to enforce these rights" (Claessens, Djankov, Lang, 2017).

\section{The Ownership Structure of Listed Saudi Corporations and Its Effect on Saudi Vision of 2030 from a CG Perspective}

The corporate governance structure upon which Saudi 2030 vision, based on McKinsey ${ }^{e e}$ s report of 2015, will be guided suffers from certain western biases implanted by the international accounting standards such as the IFRS and OECD principles of CG. For example, eighty-five years ago, Berle and Means (1932) assumed that all large public corporations would mature to a capital structure that 
is highly characterized by the separation of ownership and control. They were systematically too enthused with their assumption to the point that they overlooked cultural obstacles awaiting this hypothesis in different corners of the world's continents. It has become clear in the twentieth century that not all cultures are capable of convergence toward a specific capital-structure. In fact, the twentieth century witnessed the polarization of corporate structures between two dominant-rivaling systems of CG stemming from different cultural orientations. Therefore, Morland (2013) views CG as relying on certain identity constructs needing to be questioned. Morland argues "the way in which corporate governance initiatives address the various crises of capitalism, allows us to gloss over some crucial ontological questions that could precipitate a more rigorous questioning of capitalist practices" (2013). Consequently, Morland presents these following problems:

H1: There is a significant gap between the nature of capitalism and the crisis of control over the business in Saudi Arabia. Under this hypothesis, Morland extensively reviews the CG literature and concludes that the literature is heavily concentrated on the fiduciary duty of directors and managers to guarantee the growth of shareholders" values. Hence, the focus of such literature arguably is on „money"e, rather than on the welfare of the society, which is affected as a „sideproduct" of this pursuit.

In Saudi Arabia, the dominant form of incorporation is a family-controlled block holding and such corporations are slowing the growth of the $\mathrm{CG}^{\text {ee }} \mathrm{s}$ regulatory compliance framework. Moreover, most Saudi Listed companiese executives"e boards "e members who own fiduciary duties to all stakeholders come from dominate controlling families in the economy. For instance, three Saudi families dominate more than $41 \%$ of executive board positions in listed Saudi corporations trading on the Saudi Stock Market (Saad, 2015). In addition, these three families occupy the boards of 68 listed corporations out of 168 listed Saudi corporations trading in the stock market. In addition, 17 other families dominate other boards of Saudi Listed Corporations. These families are 
Table 1: Saudi Families Dominating Executive Board Positions

\begin{tabular}{|c|c|c|c|}
\hline Family Name & $\begin{array}{c}\text { Number of Listed } \\
\text { corporations } \\
\text { present in }\end{array}$ & $\begin{array}{c}\text { Economic Sector } \\
\text { involved in }\end{array}$ & $\begin{array}{c}\text { Number of Board } \\
\text { members in }\end{array}$ \\
\hline Al-Aissa & 25 & 13 & 28 \\
\hline Al-Rajhi & 10 & 9 & 28 \\
\hline Al-Zamil & 8 & 4 & 14 \\
\hline Aba Alkhail & 11 & 7 & 11 \\
\hline Al-Quaiz & 11 & 7 & 11 \\
\hline Al-Rashed & 10 & 6 & 11 \\
\hline Al-Gammdy & 10 & 8 & 10 \\
\hline Al-Saif & 9 & 7 & 10 \\
\hline Al-Suilm & 9 & 5 & 10 \\
\hline Al-Turki & 9 & 7 & 9 \\
\hline Al-Shiekh & 9 & 7 & 9 \\
\hline Al-Twaijri & 9 & 6 & 9 \\
\hline Al-Amran & 9 & 6 & 9 \\
\hline Al-Muhidib & 8 & 6 & 9 \\
\hline Al-Rasheed & 8 & 5 & 9 \\
\hline Al-Saleh & 9 & 5 & 9 \\
\hline Ali Rida & 8 & 5 & 9 \\
\hline
\end{tabular}

Source: Saad (2015) Maaal Economic Newspaper on the 18th of March 2015

In addition, CG legislation in Saudi Arabia is still slowly moving from voluntary to obligatory because family-owned firms, which is the dominant form of incorporation, are stifling corporate growth by their reluctance to open their equity to outside shareholders, as argued by the OECD report of Koldertsova (2017). 
Moreover, the determinants promoting or influencing these concentrated ownership structures in Saudi Arabia shall have been taken into account by McKinsey's report of 2015 which positively relies on the roles of the private sector to accomplish a major part of its proposed economic model: families own $75 \%$ of listed companies, while government and individual founders own just $25 \%$ of listed companies (Al-Zuhair, 2008). Thus, controlling families in Saudi Arabia have the power and interest to expropriate Minority shareholders. Hence, these families are more likely to continue to persist in doing so under the direction of Saudi 2030 vision. Because Vision 2030, as it stands, has not taken into account the nature of the networked economy into account when, in fact, controlling families are found to neither support nor encourage legal reforms enhancing Minority shareholders" rights. Instead, these families are found to lobby against such reforms due to their prime focus on money, rather than on the welfare of the society, which is affected as a „side product" of their pursuit. Hence, the legal effect becomes minimal in such an environment Morland (2013). Morland (2013) arguably views capitalism as striving on flows; hence, in the process, most of the humanitarian values escape as the focus is on production and efficiency rather than on the sovereignty of the workforce. Contestably, Morland views the outcome of that to be the enlargement of social classes leading to a confrontation with the problems of inequality, disenfranchisement, and poverty.

Therefore, the Saudi vision of 2030 is highly advised not to commit to a CG structure that is highly focused on flow at the expense of sovereignty, as one of the side products of the vision is to transform the Saudi government from a sovereign government into an efficient, self-sufficient government (Nurunnabi 2017). The rationale behind such recommendation stems from the fact that, as it stands, $75 \%$ of the listed Saudi corporations are family owned (Al-Zuhair, 2008) and they are more likely to continue to manifest themselves in the governance of emerging economic systems such as Saudi Arabia's as their survival is dependent on the institutional context, which needs a major reforms. 


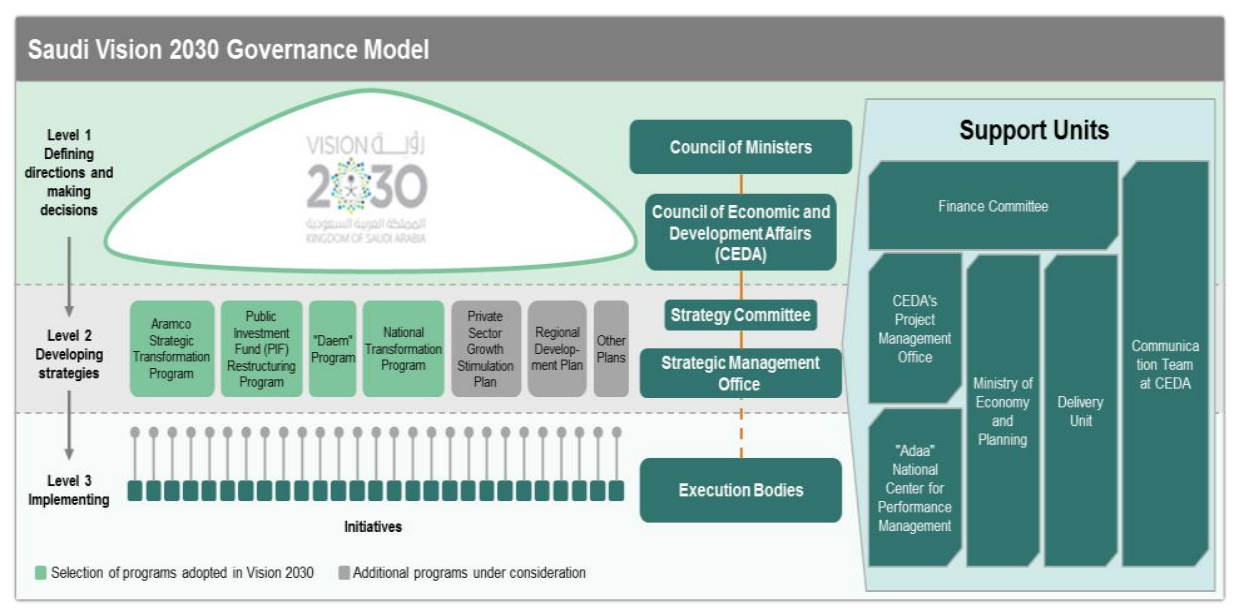

Fig. 1: Vision 2030 Proposed Hierarchical Governance Structure \& Crisis of Control

(Vision 2018)

In biological terms, a ,rhizome ${ }^{\text {ee }}$ refers to a form of plant that extends itself through horizontal tube-like root system and can in this way create endless new plants" (Morland, 2013). Hence, exploring CG in a rhizomatic way might arguably lead to a mind-shift. Such shift might be capable of directing attention away from delineating units that operate in accordance with certain foundational principles to be open to "dimensions or rather directions in motion" (Deleuze \& Guattari, 1988, (Moshashai, Leber et al. 2018)).

H2: there are Factors that can influence the implementation of Saudi 2030 vision from a $\mathrm{CG}$ perspective.

\section{Socio-Economical Factors Influencing the CG Regime \& Implementation of Vision 2030}

In terms of the Government Restructuring program, the Saudi government is planning to "organize itself with agility, continuously restructuring and aligning their systems to national priorities. We have already started moving along this path by eliminating supreme councils and establishing the Council of Political and Security Affairs and the Council of Economic and Development Affairs. 
These reforms have helped to speed strategy development and decision-making, as well as enhance performance. We will continue this careful restructuring, comprehensively and gradually, based on our clear priorities. We have approved the strategic directions determined by our government agencies. Existing roles have been reviewed to align with our future economic and social need. The Kingdom's agencies are currently undergoing a wave of reforms and transformation.

To manage this momentum and ensure all efforts are coordinate" (Saudi Vision, 2016). There are a few challenges the new reformed government agencies will face in implementing vision 2030: Saudi Government should be aware of members of listed-Saudi corporations se controlling families at the Saudi House of Ministers and Saudi House of Consultancy. These members of listed-Saudi corporations"e controlling families are more likely to cultivate a conservative agenda that protects established forms of organized capitalism embracing the concentrated ownership choices of corporate structures.

\section{Institutional Factors Influencing the CG Regime of Saudi Economy \& Implementation of Vision 2030}

According to Vision 2030, "We adopted the principle of performance measurement, and made sure it is properly used in our evaluation of all government agencies, their programs, initiatives and executives. We established the Center for Performance Management of Government Agencies to institutionalize these efforts for the long-term and built performance dashboards to promote accountability and transparency. To ensure the realization of Saudi Arabia's Vision for 2030, we are preparing to launch a group of executive programs that will have a significant impact on implementation. We are identifying opportunities for partnering with the private sector, as well as innovative administrative and funding approaches. We are detailing specific initiatives that have clear performance indicators." Nevertheless, vision 2030 
might face a few challenges regarding its implied "institutionalization through executives a top-down implementation method, as seen in the CG section. Moreover, such difficulty will be substantiated by the private sector as they have not been great when it comes to complying with current SCGR"

\section{Privatization Factors Influencing the CG Regime of Saudi Economy}

According to vision 2030, "We are in the process of determining additional sectors suitable for privatization. Our goal is to create a comprehensive privatization program. We will make use of international best practices, transfer knowledge and achieve our goals in a balanced and scientific manner". Due to the increasing evidence that newly privatized markets have failed to set up viable securities, legal scholars are focused on the dichotomy between dispersed and concentrated ownership structure. Nevertheless, the Saudi Company Law of 1965 does not effectively protect minority shareholder's rights. In fact, the SCL of 1965 is rather found to empower majority shareholders with unrestricted control over their companies to the point where majority shareholders are capable of causing abuses and injustice (Al-Madani, 2011). For instance, in accordance with SCL 1965, hence, the current state of the Saudi CL of 1965 is considered outdated and this outdated version fails to protect Saudi minority shareholders (Al-Madani, 2011, Al-Zahrani, 2013). Despite the Saudi government"s intention to reform CG, the Saudi CL of 1965 "has not been modified to any significant degree; it is still not sufficiently effective, and does not address many important points relating to shareholders"e rights in listed companies"(Al-Zahrani, 2013).

Moreover, the board of SCMA, which was created via the Saudi Capital Market law of 2004, has utilized its powers, granted by the King, to legislate the issuance of CG regulations in 2006 after the first market crash (Al-Zaid, 2012). Nevertheless, adherence to Saudi CGRs was made obligatory in 2010 and listed Saudi corporations still adhere to CG regulations on a 'comply or explain basis' 
(Al-Zahrani, 2013). The objective of the SCGRs issued by SCMA is to provide Saudi listed corporations and their shareholders with a general guideline for best practice.

In addition, there is an apparent contradiction between $\mathrm{SCMA}^{\mathrm{ce}} \mathrm{s}$, guidance, Saudi Corporate Governance Regulations (SCGRs) and the obligatory regulations of Saudi Company Law of 1965. For instance, protecting minority shareholders is a fundamental objective of the OECD principles of CG issued in 2004. And, member countries such as Saudi Arabia should take this fundamental objective seriously into consideration when implementing a set of CG regulations. Those OECD principles of CG capable of protecting minority shareholders include: 1) Rights of Shareholders; 2) Equitable Treatment of Shareholders; 3) Role of Shareholders; 4) Disclosure and Transparency; 5) Responsibility of the Board. Nevertheless, the Saudi version of those CG regulations (SCGRs) issued by SCMA in 2006 only include: 1) an introduction and definition of CG; 2) the rights of shareholders and the GM; 3) disclosure and transparency; 4) the board of directors; 5) the closing provisions. Hence, SCMA needs to improve it SCGRs to cover all areas as emphasized by the OECD principles of 2004. In addition, SCMA needs to provide the necessary legal awareness programs for minority shareholders to implement the appropriate devices to aid minority shareholders in exercising their rights and encounter any oppression imposed on them by majority shareholders (Al-Zahrani, 2013b).

\section{Conclusions}

Despite of the recent practical attempts undertaken by SCMA, the current status of the Saudi CG framework does not constitute effective legal, regulatory and institutional foundations capable of carrying Saudi vision of 2030 forward. Moreover, the current status of CG in the whole Middle East and North Africa (MENA) region, consisting of countries sharing the same culture, oil based economies, and religion as Saudi Arabia, is very similar to Saudi Arabia, as 
indicated by the OECD report of 2011. Hence, such integration, based on the positive results of the empirical and qualitative evidence found in other studies and presented through this paper, confirms the criticality of the variables extracted from the literature. Hence, this proposed multi-dimensional framework contributes a greater understanding of socio-economical, institutional, and privatization factors which are very crucial to consider when assessing Saudi Vision 2030 in terms of the needed CG framework reform upon which such vision can be carried forward. The challenge is to make sure that international and national commitments to anticorruption as well as leadership calls for anti-bribery at the board level trickle down through the whole company to every last employee on the ground in countries around the world.

\section{References}

Alfordy, Faisal (2016). An Assessment of the Impact of Saudi Arabia Culture on Corporate Governance on Minority Shareholders ${ }^{e e}$ Rights. The 29th Annual Conference of the British Academy of Management (BAM), Portsmouth, UK. From the 8th - 10th September 2016.

Al-Janadi, Y., Rahman, R.A., \& Omar, N.H. (2012). The level of voluntary disclosure practices among public listed companies in Saudi Arabia and the uae: Using a modified voluntary disclosure index. International Journal of Disclosure and Governance, 9(2), 181-201.

AlRuthia, Y., M. A. Alsenaidy, H. K. Alrabiah, A. AlMuhaisen and M. Alshehri (2018). "The status of licensed pharmacy workforce in Saudi Arabia: a 2030 economic vision perspective." Human resources for health 16(1): 28.

Al-Madani, M.H. (2011). The reform of minority shareholder protection in Saudi Arabia and Dubai in private companies (Doctoral dissertation, University of Leeds). Retrieved from http://etheses.whiterose.ac.uk/id/eprint/3354 
Al-Twaijry, A.A., Brierley, J.A., \& Gwilliam, D.R. (2003). The development of internal audit in saudi arabia: An institutional theory perspective. Critical Perspectives on Accounting, 14(5), 507-531.

Al-Zahrani, Y.A. (2013). Rights of shareholders under Saudi company law (Doctoral dissertation, Brunel University) 232-219-77. Retrieved from http://bura.brunel.ac.uk/bitstream/2438/8284/1/FulltextThesis.pdf

Al-Zahrani, Y.A. (2013b). The corporate governance in Saudi listed companies. International Journal of Humanities and Management Sciences (IJHMS), 1, (4), 243-254.

Al-Zaid, A.A. (2012). Corporate governance in the kingdom of Saudi Arabia (Doctoral dissertation, University of Kansas). Retrieved from https://kuscholarworks.ku.edu/handle/1808/11162.

Al-Zuhair, M.M. (2008). Privatization programs, ownership structures, and market development: The role of country characteristics on defining corporate governance standards (Doctoral dissertation, The George Washington University). Retrieved from Pro-Quest Database. (Accession No. 9780549687207).

Berle, A.A., \& Means, G.C. (1932). Modern corporation and private property.

Code of Corporate Governance for Public Listed Companies Forth Edition 2017. www.soharpower.com/Uploadimage/ccg\%20eng.pdf

Deane, S. (2006). Corporate governance: From compliance obligation to business imperative. Corp. Gov. Advis, 14(4), 13-20.

Krane, J. and F. Majid (2018). "Women Driving in Saudi Arabia: Ban Lifted, What are the Economic and Health Effects?" Issue Brief 6. 
Koldertsova, A. (2017). The second corporate governance wave in the Middle East and north africa. OECD Journal: Financial Market Trends, 2017 (2), 219226.

La Porta, R., Lopez-De-Silanes, F., Shleifer, A., \& Vishny, R. (2002). Investor protection and corporate valuation. The journal of finance, 57(3), 1147-1170.

Moshashai, D., A. M. Leber and J. D. Savage (2018). "Saudi Arabia plans for its economic future: Vision 2030, the National Transformation Plan and Saudi fiscal reform." British Journal of Middle Eastern Studies: 1-21.

Morland, M. (2013). The Relationship between Identity Crises and Crises of Control. Journal of business ethics, 114(1), 1-14.

Nurunnabi, M. (2017). "Transformation from an oil-based economy to a knowledge-based economy in Saudi Arabia: the direction of Saudi vision 2030." Journal of the Knowledge Economy 8(2): 536-564.

OECD Principles of Corporate Governance. (2004) .Retrieved Feb 18, 2013, from http://www.oecd.org/corporate/ca/corporategovernanceprinciples/31557724.pdf.

Rossouw, D., \& Sison, A.G. (2006). Global perspectives on the ethics of corporate governance, (pp. 5-9). New York: Palgrave Macmillan.

Rossouw, G. (2009). The ethics of corporate governance: Global convergence or divergence? International Journal of Law and Management, 51(1), 43-51.

Saad, M. (2015, Mar 18th). Namely 3 Saudi families dominate $41 \%$ of board of directors in saudi listed corporations. Maaal Economic Newspaper, p. 5. Retrevied from http://www.maaal.com/archives/55910.

Saudi Vision 2030 (2016), Retrieved November 10th, 2016, from http://vision2030.gov.sa/en 
The Saudi Stock Exchange (Tadawul) :

http://www.tadawul.com.sa/wps/portal/HomeEn

Saudi Arabian Monetary Agency (SAMA). (2018). The Monetary regulatory agency of Saudi Arabia. (http://www.sama.gov.sa/sites/samaen/AboutSAMA/Pages/Home.aspx.

Saudi Vision 2030: http://vision2030.gov.sa/en

Vision, S. A. s. (2018). 2030. How to achieve our vision. June 2017. 